[Chem. Pharm. Bull.

35( 4$) 1353-1359(1987)$

\title{
Studies on the Conformation of 1-Aryl-1-nitrosoureas and Related Compounds
}

\author{
Masayuki Tanno* and Shoko Sueyoshi \\ National Institute of Hygienic Sciences, 1-18-1 Kamiyoga, \\ Setagaya-ku, Tokyo 185, Japan
}

(Received July 31, 1986)

\begin{abstract}
The carbon-13 nuclear magnetic resonance spectra of 1-aryl-3,3-dialkyl-1-nitrosoureas and related compounds were measured at about $-40{ }^{\circ} \mathrm{C}$, and their chemical shifts were assigned. The conformations of the $N$-nitroso compounds having the 1-aryl-1-nitrosoureido group were established through comparisons with $N$-alkyl- $N$-nitrosoanilines, and the decomposition mechanism of 1-aryl-3,3-dialkyl-1-nitrosoureas is discussed on the basis of the results.
\end{abstract}

Keywords - 1-aryl-3,3-dialkyl-1-nitrosourea; 1-aryl-1-nitrosourea; $N$-nitrosourea; $N$-nitrosoacetanilide; $N$-nitrosoaniline; triazene; nitrosyl radical; $E-Z$ conformation; ${ }^{13} \mathrm{C}$-NMR

In an investigation of the decomposition of 1-aryl-3,3-dialkyl-1-nitrosoureas (1) at room temperature, we have found a difference in decomposition between 3,3-diethyl-1-(2-tolyl)-1nitrosourea (1a) and its 4-tolyl isomer (1b) in chloroform or carbon tetrachloride. While the 2tolyl derivative (1a) decomposed to afford the triazene (11a), the positional isomer (1) gave mainly the nitro compound (12) and the urea (13b) besides the triazene (11b) ${ }^{11}{ }^{1}$ We considered that the structural features of these $N$-nitrosoureas would be related to the reactivity differences. Although the assignment of the carbon- 13 nuclear magnetic resonance $\left({ }^{13} \mathrm{C}\right.$ NMR) spectra of 1-aryl-1-nitrosoureas $(\mathbf{1 a}, \mathbf{b})$ has already been reported, ${ }^{1)}$ we did not discuss the structural features in detail, including the assignment of the $E-Z$ isomers. This paper describes studies on the structural features of 1-aryl-1-nitrosoureas and related compounds.

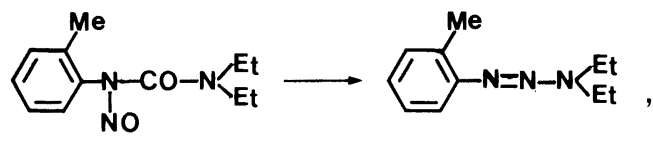

1a

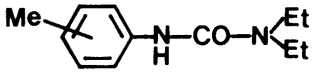

$13 \mathrm{a}, \mathrm{b}$

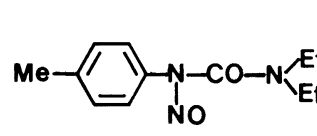

$1 b$
$11 \mathbf{a}$<smiles>CCN(CC)/N=N/c1ccc(C)cc1</smiles>

$11 \mathrm{~b}$<smiles>CCN(CC)C(=O)Nc1ccc(C)cc1[N+](=O)[O-]</smiles>

12

Chart 1

\section{Results and Discussion}

The carbon chemical shifts of the $N$-nitroso compounds are collected in Tables I and II. The spectra of the nitrosoureas $(\mathbf{1}-\mathbf{3}, \mathbf{5}, \mathbf{6})$ and the nitrosoacetanilides $(\mathbf{4})$ were measured at about $-40^{\circ} \mathrm{C}$, since the compounds are unstable at room temperature. 
The conformational analysis of $N$-alkyl- $N$-nitrosoanilines has already been studied by proton nuclear magnetic resonance $\left({ }^{1} \mathrm{H}-\mathrm{NMR}\right.$ spectroscopy). ${ }^{2)}$ However, the nature of the conjugation between the amine nitrogen and the phenyl ring in these nitrosoanilines has not been clarified from the ${ }^{1} \mathrm{H}-\mathrm{NMR}$ data. In order to elucidate the conformation of the $\mathrm{N}$ nitrosoureas $(\mathbf{1}-\mathbf{3}, \mathbf{5}, \mathbf{6})$ and the $N$-nitrosoacetanilides $(\mathbf{4})$, we first assigned the carbon chemical shifts of the phenyl ring carbons of $N$-alkyl- $N$-nitrosoanilines (7-10). As shown in Table II, the carbon signals of the $N$-alkyl- $N$-nitrosoanilines (7-10) indicated the presence of an equilibrium mixture of $Z$ and $E$ isomers, though the tert-butyl derivative (9) existed only as the $E$ isomer. The chemical shifts of $\mathrm{C}^{1}$ of the $E$ isomers were always observed at higher field than those of the corresponding $Z$ isomers.

A study of the electronic spectra of $N$-alkyl- $N$-nitrosoanilines ${ }^{3)}$ indicated that $N$-ethyl- $N$ nitrosoaniline (7c) and $N$-nitrosoindoline (10) exist almost wholly in the $Z$ form and take a planar or near-planar conformation. In other words, it appears that a conjugated system is present between the aryl ring and the amine nitrogen. The $N$-nitrosoanilines $(\mathbf{7 a}, \mathbf{8 , 9})$ having a bulky group at the nitrogen or possessing an ortho methyl group on the aryl ring are highly twisted. ${ }^{3)}$ In fact, the conjugation effects are reflected in the chemical shifts at $C^{2}$ of the aryl ring. The $\mathrm{C}^{2}$ signal of the $Z$ form of $\mathbf{7 b}$ appears at higher field as compared with that of $\mathbf{9 b}$ (only $E$ form). This may be attributed to the contribution of the resonance form in the $Z$ isomer, as shown in Chart 2. On the other hand, the $N$-alkyl carbon chemical shifts of the $Z$ isomers of $N$-nitrosoamides or $N$-nitrosoanilines have been observed at higher field than those of the corresponding $E$ isomers. $^{4)}$<smiles>CCn1c(=O)n(C)n(CC)c1=O</smiles>

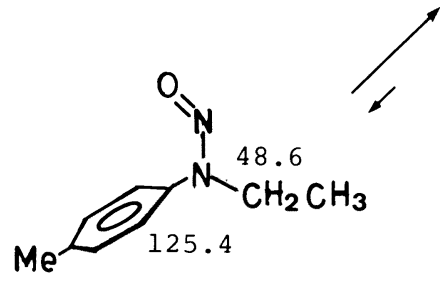

$E$

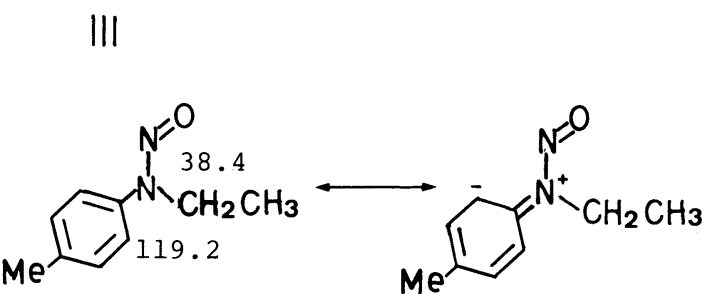

$Z$

$7 \mathbf{b}$

From the assignments for the $N$-nitrosoanilines (7-10), the $E-Z$ conformations of the aliphatic $N$-nitrosoureas $(\mathbf{5 , 6 )}$ can be deduced, and the results are shown in Table II. Consequently, it was revealed that the carbonyl carbon of the $E$ form of $\mathbf{6}$ resonated at lower field than that of the $Z$ form. On the basis of the data for compounds 5-10, the chemical shifts of the $N$-nitrosoureas of aryl type $(1-4)$ could also be assigned as summarized in Table I. The chemical shifts of $\mathrm{C}^{2}$ (or $\mathrm{C}^{6}$ ) and the carbonyl are noted in Chart 3 .

The disubstituted $N$-nitrosoureas $(2,3)$ and the $N$-nitrosoacetanilides (4) exist only in the $E$ conformer, in which the NO group is located anti to the $\mathrm{CO}$ group, in the range of about $-40^{\circ} \mathrm{C}$ to $10^{\circ} \mathrm{C}$. The possible conformations are shown as forms $\mathrm{I}-\mathrm{V}$ in Chart 4 . In forms II and $\mathrm{V}$, the $\mathrm{NO}$ group interacts unfavorably with the $\mathrm{X}$ group and the $\mathrm{CO}$ group, respectively. The NO group and the CO group should be hindered in form IV if an ortho-substituent is 


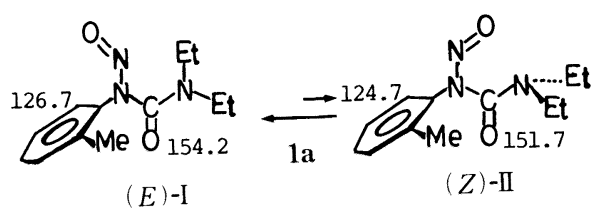

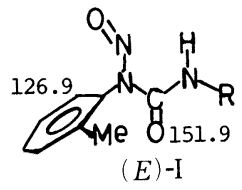

$3 \mathbf{a}: \mathrm{R}=$ iso $-\mathrm{Pr}$

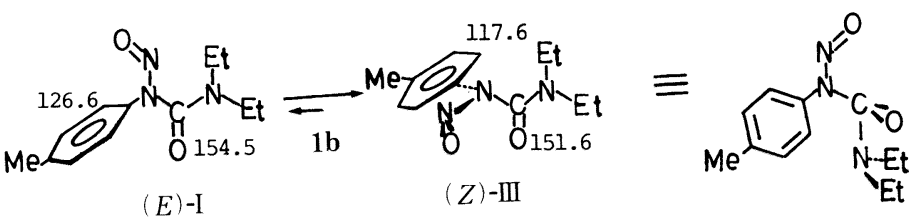

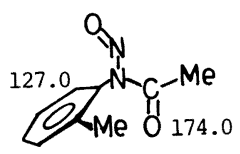

(E) -I

4a<smiles>CN(N=O)C(=O)N1CCCCC1</smiles>

5

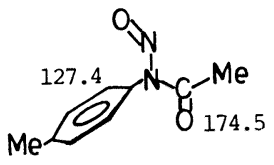

(E)-I

$4 \mathrm{~b}$

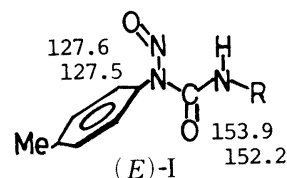

$2 \mathrm{~b}: \mathrm{R}=\mathrm{Me}$

$3 \mathrm{~b}: \mathrm{R}=$ iso $-\mathrm{Pr}$<smiles>[Y]C1=CC=CC1N(N=O)C(=O)[Y]#CC</smiles>

(E)-I<smiles>C#C[C@H]1CCCN(C(=O)N(N=O)C(C)C)C1</smiles>

Chart 3

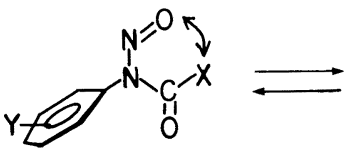

(Z)-II<smiles>[Y][Y]1c(=O)n(N=O)c2ccc([Y])cc12</smiles>

(Z) - III

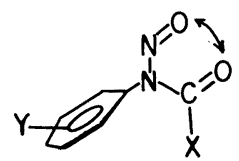

(Z) $-\mathrm{V}$

(E) -IV

Chart 4

present on the phenyl ring. Consequently, the preferred conformer of the disubstituted nitrosoureas $(2,3)$ and the nitrosoacetanilides $(4)$ should be form I. ${ }^{5}$ )

On the other hand, observation of the two sets of signals of the trisubstituted $\mathrm{N}$ nitrosoureas (1) indicates a possible conformational equilibrium involving forms I-III. Conformer I (major form) and conformer $\mathrm{II}^{6)}$ (minor form) are observed for the (2tolyl)nitrosourea (1a). In the 4-tolyl isomer (1b), conformer I and conformer III $^{7)}$ are observed, and the latter is predominant. 
As the substituent $\mathrm{X}$ is larger in the trisubstituted nitrosoureas $(\mathbf{1} \mathbf{b}-\mathbf{d})$ than in the disubstituted nitrosoureas $(\mathbf{2}, \mathbf{3})$, the NO group in $\mathbf{1 b}-\mathbf{d}$ is subject to steric repulsion by the two ethyl groups at the $\mathrm{N}^{3}$ position. The hindrance between the NO group and the $\mathrm{X}$ group in form II may permit the coexistence of conformer III. Actually, the carbon signals of the alkyls at the $\mathrm{N}^{3}$ position in the trisubstituted nitrosoureas show broad peaks as compared with those in the disubstituted derivatives. This phenomenon seems to be due to restricted rotation about the $\mathrm{CO}-\mathrm{N}^{3}$ bond. In conformer III, the $\mathrm{Ph}-\mathrm{N}-\mathrm{NO}$ part is approximately coplanar, and the $\mathrm{N}^{1}-\mathrm{CO}$ bond is twisted. The $\mathrm{C}^{2}$ or $\mathrm{C}^{6}$ signal of the (4-tolyl)nitrosoureas $(\mathbf{1} \mathbf{b}-\mathbf{d})$ appears at higher field in the planar form III than in the nonplanar form I. However, the nonplanar form I is preferred to form III in the 2-tolyl compound (1a) due to the increase of steric hindrance between the ortho methyl group and the $\mathrm{X}$ group.

Next we will discuss the nature of the decomposition of the $N$-nitroso compounds, using the above information on their conformations. 1-Methyl-3,3-(pentamethylen)-1-nitrosourea (5), which exists only as the $E$ form, was stable at room temperature during $10 \mathrm{~d}$. In contrast, the isopropyl derivative (6), consisting of a mixture of $Z$ and $E$ conformers, decomposed to generate $\mathrm{CO}_{2}$ under the same conditions. This feature was confirmed by the appearance of the $\mathrm{CO}_{2}$ stretching vibration at $2320 \mathrm{~cm}^{-1}$ with the passage of time. In the intramolecular rearrangement to the diazoester intermediate, ${ }^{8)}$ the presence of the $Z$ form (like conformer II) having a coplanar $\mathrm{O}=\mathrm{N}-\mathrm{N}-\mathrm{C}=\mathrm{O}$ moiety in the ground state may be of importance, as shown in Chart 3. The trisubstituted (2-tolyl)nitrosourea (1a) containing the $Z$ form of the coplanar $\mathrm{O}=\mathrm{N}-\mathrm{N}-\mathrm{C}=\mathrm{O}$ (conformer II) decomposed rapidly to the triazene (11a) with the evolution of $\mathrm{CO}_{2}$ at room temperature. On the other hand, the (4-tolyl)nitrosourea (1b) adopts mainly a different $Z$ form (conformer III). Thus, the 4-tolyl derivative (1b) gave the corresponding triazene (11b) in lower yield than the 2-tolyl isomer (1a). ${ }^{1}$

TABLE I. ${ }^{13} \mathrm{C}$-NMR Chemical Shifts ${ }^{a)}(\mathrm{ppm})$ of $N$-Nitrosoureas $(\mathbf{1}-\mathbf{3})$ and $N$-Nitroacetanilides (4)

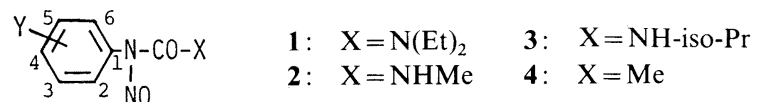

\begin{tabular}{|c|c|c|c|c|c|c|c|c|c|c|c|c|c|c|}
\hline \multirow{4}{*}{$\begin{array}{c}\text { Compd. } \\
\mathbf{1 a}^{1)}\end{array}$} & \multirow{4}{*}{$\begin{array}{r}\mathrm{Y} \\
2-\mathrm{Me}\end{array}$} & \multirow{3}{*}{$\frac{\text { Form }^{g)}}{\left\{I^{e)}\right.}$} & \multirow{3}{*}{$\frac{C-1}{134.0}$} & \multirow{3}{*}{$\begin{array}{c}\text { C-2 } \\
136.4\end{array}$} & \multirow{3}{*}{$\begin{array}{c}\text { C-3 } \\
130.9\end{array}$} & \multirow{3}{*}{$\begin{array}{c}\text { C-4 } \\
127.3\end{array}$} & \multirow{3}{*}{$\begin{array}{c}\text { C-5 } \\
129.9\end{array}$} & \multirow{3}{*}{$\begin{array}{c}\text { C-6 } \\
126.7\end{array}$} & \multirow{3}{*}{$\frac{\mathrm{CO}}{154.2}$} & \multirow{3}{*}{$\begin{array}{c}\mathrm{Y} \\
18.0\end{array}$} & \multicolumn{4}{|c|}{$X^{c)}$} \\
\hline & & & & & & & & & & & \multicolumn{2}{|c|}{$\mathrm{N}^{3}-\mathrm{C}$} & \multicolumn{2}{|c|}{$\mathrm{C}-\mathrm{Me}$} \\
\hline & & & & & & & & & & & 40.8 & 42.2 & 13.4 & 13.6 \\
\hline & & I II & d) & 136.8 & 132.0 & 126.9 & 129.1 & 124.7 & 151.7 & 18.6 & 40.9 & d) & 12.8 & d) \\
\hline \multirow{2}{*}{$1 b^{1)}$} & \multirow{2}{*}{ 4-Me } & I & 131.4 & 126.6 & 129.9 & 139.7 & 129.9 & 126.6 & 154.5 & 21.2 & 41.2 & d) & 13.6, & d) \\
\hline & & III $^{e)}$ & 135.3 & 117.6 & 130.3 & 137.6 & 130.3 & 117.6 & 151.6 & 21.0 & 41.4 & 42.7 & 12.3 & 13.7 \\
\hline \multirow{2}{*}{ 1c } & \multirow{2}{*}{$\mathrm{H}$} & I & 134.1 & 126.9 & 129.3 & 129.6 & 129.3 & 126.9 & 154.4 & & d) & & & \\
\hline & & III $^{e)}$ & 137.7 & 117.4 & 129.8 & 127.6 & 129.8 & 117.4 & 151.5 & & 41.5 & 42.8 & 12.4 & 13.7 \\
\hline \multirow{2}{*}{ 1d } & \multirow{2}{*}{$4-\mathrm{Cl}$} & I & 132.4 & 128.6 & 129.5 & 135.4 & 129.5 & 128.6 & 154.1 & & d) & & & \\
\hline & & $\mathrm{III}^{e)}$ & 136.3 & 118.7 & 129.9 & 133.0 & 130.0 & 118.7 & 151.1 & & 41.6, & 42.8 & 12.4 & 13.9 \\
\hline 2b & 4-Me & I & 129.5 & 127.6 & 130.0 & 140.2 & 130.0 & 127.6 & 153.9 & 21.3 & 27.2 & & & \\
\hline $2 e$ & 4-MeO & I & 124.3 & 129.0 & 114.5 & 160.2 & 114.5 & 129.0 & 154.0 & 55.4 & 27.3 & & & \\
\hline $3 a$ & $2-\mathrm{Me}$ & I & 131.8 & 136.3 & $130.3^{b)}$ & 128.0 & $130.8^{b)}$ & 126.9 & 151.9 & 17.4 & 43.1 & & 22.8 & \\
\hline 3b & 4-Me & I & 129.4 & 127.5 & 130.0 & 140.0 & 130.0 & 127.5 & 152.2 & 21.3 & 43.1 & & 22.7 & \\
\hline $3 c$ & $\mathrm{H}$ & I & 132.1 & 127.8 & 129.3 & 130.0 & 129.3 & 127.8 & 152.1 & & 43.2 & & 22.7 & \\
\hline $3 e$ & 4-MeO & I & 124.3 & 129.0 & 114.5 & 160.1 & 114.5 & 129.0 & 152.3 & 55.4 & 43.8 & & 22.8 & \\
\hline $4 a$ & $2-\mathrm{Me}$ & I & 131.5 & 135.7 & $130.8^{b)}$ & 127.8 & $130.4^{b)}$ & 127.0 & $174.0^{\circ}$ & 17.2 & & & 22.9 & \\
\hline 4b & 4-Me & I & 129.0 & 127.4 & 130.2 & 140.3 & 130.2 & 127.4 & 174.5 & $23.1^{f)}$ & & & $23.1^{f)}$ & \\
\hline $4 d$ & $4-\mathrm{Cl}$ & I & 130.0 & 129.2 & 129.7 & 135.9 & 129.7 & 129.2 & 174.0 & & & & 23.0 & \\
\hline
\end{tabular}

a) Measured in $\mathrm{CDCl}_{3}$ at $-40^{\circ} \mathrm{C}$. b) Assignments may be reversed. c) Et groups in 1a d show broad signals. d) Not observable under the experimental conditions. e) The intensities of the signals are overwhelmingly stronger than those of the other isomer. ${ }^{15} f$ ) Coincidences. $g$ ) Forms I-III are shown in Chart 4. 


\section{Conclusion}

From these results, the effective conformer for the diazoester intermediate formation by $N$-nitroso compounds of aryl type $(\mathbf{1}-\mathbf{4})$ seems to be conformer II, in which the $\mathrm{O}=$ $\mathrm{N}-\mathrm{N}-\mathrm{C}=\mathrm{O}$ part is coplanar. The disubstituted $\mathrm{N}$-nitrosoureas of aryl type $(\mathbf{2}, \mathbf{3})$ and the $\mathrm{N}$ -

TABLE II. ${ }^{13} \mathrm{C}-\mathrm{NMR}$ Chemical Shifts ${ }^{a)}(\mathrm{ppm})$ of $N$-Nitrosoureas $(\mathbf{5}, \mathbf{6})$ and $N$-Nitrosoanilines $(\mathbf{7}-\mathbf{1 0})$
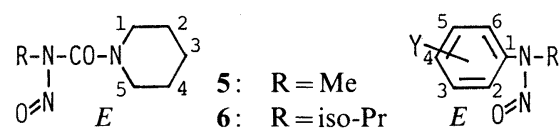

$\begin{array}{ll}\text { 7: } & \mathrm{R}=\mathrm{Et} \\ \text { 8: } & \mathrm{R}=\sec -\mathrm{Bu} \\ \text { 9: } & \mathrm{R}=\text { tert }-\mathrm{Bu}\end{array}$<smiles>Cc1cccc2c1N(N=O)CC2</smiles>

\begin{tabular}{|c|c|c|c|c|c|c|c|c|c|c|c|c|c|}
\hline Compd. & $\mathrm{Y}$ & Form $^{g)}$ & $\mathrm{C}-1$ & C-2 & $C-3$ & C-4 & $C-5$ & C-6 & $\mathrm{CO}$ & Y & $\mathrm{N}-\mathrm{C}$ & $\underset{\mathrm{C}-\mathrm{CH}_{2}-}{\mathrm{R}}$ & $\mathrm{C}-\mathrm{Me}$ \\
\hline 5 & & $E$ & $49.4^{b, c)}$ & 25.9 & 24.3 & 25.9 & 46.0 & & 154.2 & & 29.8 & & \\
\hline \multirow{2}{*}{6} & & $E^{e)}$ & $48.8^{b, c)}$ & 26.3 & 24.3 & 25.6 & 45.2 & & 153.1 & & 45.4 & & 18.6 \\
\hline & & $Z$ & $46.6^{b, c)}$ & 26.1 & 24.0 & 25.4 & 44.2 & & 151.6 & & 53.3 & & $22.9,20.6$ \\
\hline \multirow{2}{*}{$7 a$} & \multirow{2}{*}{$2-\mathrm{Me}$} & $E$ & 137.5 & 135.9 & 130.9 & $126.8^{f)}$ & 129.3 & 126.2 & & $17.8^{f)}$ & 48.8 & & 14.1 \\
\hline & & $Z$ & 140.2 & 134.9 & 131.5 & $126.8^{f)}$ & 129.1 & 127.7 & & $17.8^{f)}$ & 41.7 & & 11.0 \\
\hline \multirow{2}{*}{$7 b$} & \multirow{2}{*}{ 4-Me } & $E$ & d) & 125.4 & 129.1 & d) & 129.1 & 125.5 & & 20.4 & 48.6 & & 14.2 \\
\hline & & $Z$ & 138.5 & 119.2 & 129.5 & 136.5 & 129.5 & 119.1 & & 20.1 & 38.4 & & 11.6 \\
\hline \multirow{2}{*}{$7 c$} & \multirow{2}{*}{$\mathrm{H}$} & $E$ & d) & 126.2 & 129.3 & 128.8 & 129.3 & 126.2 & & & 48.6 & & 14.2 \\
\hline & & $Z$ & 141.5 & 119.5 & 129.4 & 127.1 & 129.4 & 119.5 & & & 38.8 & & 11.6 \\
\hline \multirow{2}{*}{$8 a$} & \multirow{2}{*}{$2-\mathrm{Me}$} & $\int E$ & 136.5 & 136.2 & 131.5 & $126.6^{f)}$ & 130.8 & 126.5 & & $18.2^{f)}$ & 62.2 & 29.5 & $20.0,10.9$ \\
\hline & & $Z$ & 138.8 & 136.0 & 130.8 & $126.6^{f)}$ & 129.1 & 126.4 & & $18.2^{f)}$ & & 27.3 & $18.8,11.0$ \\
\hline \multirow{2}{*}{$8 b$} & \multirow{2}{*}{ 4-Me } & $E$ & 134.2 & 127.2 & 129.9 & 139.0 & 129.5 & 127.2 & & 21.0 & 62.0 & 28.6 & $20.0,10.9$ \\
\hline & & $Z$ & 138.3 & 126.3 & 129.6 & 137.6 & 129.6 & 126.3 & & 20.9 & 51.9 & 27.1 & $17.6,11.1$ \\
\hline $9 a$ & $2-\mathrm{Me}$ & $E$ & 137.4 & 136.5 & 130.6 & 127.2 & 129.0 & 126.4 & & 18.2 & 61.7 & & 30.2 \\
\hline $9 b$ & 4-Me & $E$ & 134.6 & 128.2 & 129.8 & 138.9 & 129.8 & 128.2 & & 21.0 & 61.1 & & 29.9 \\
\hline \multirow[b]{2}{*}{10} & & $\{E$ & d) & 117.4 & 126.2 & 126.5 & 127.5 & d) & & & 59.9 & 26.8 & \\
\hline & & $\left\{\begin{array}{l}z \\
Z\end{array}\right.$ & 140.8 & 118.8 & 128.0 & 126.1 & 126.8 & 132.0 & & & 45.4 & 26.0 & \\
\hline
\end{tabular}

a) Measured in $\mathrm{CDCl}_{3}$ at $-40{ }^{\circ} \mathrm{C}$ for 5 and 6, and at room temperature for $\left.7-10 . \quad b\right)$ Assignments for $\mathrm{C}^{1}$ and $\mathrm{C}^{5}$, or for $\mathrm{C}^{2}$ and $\mathrm{C}^{3}$ may be reversed. c) The carbon signals of the piperidine ring are broad except for $\mathrm{C}^{3} . d$ ) Not observable under the experimental conditions. e) The intensities of the signals are overwhelmingly stronger than those of the other isomer. ${ }^{15}$ $f$ ) Coincidences. $g$ ) Form $E$ has the NO group located anti to the $\mathrm{CO}$ group or syn to the aryl ring.

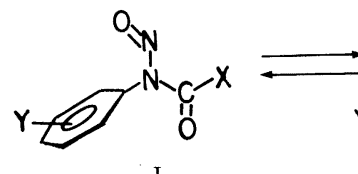

I<smiles>[X]C(=O)N(N=O)C1C=CC=C1[Y]</smiles>

II<smiles>[X]C(=O)N(N=O)c1ccc([Y])cc1</smiles>

III<smiles>[X]C(=O)ON=Nc1ccc([Y])cc1</smiles><smiles>[Y]C(=O)Nc1ccc([Y])cc1</smiles><smiles>CI</smiles>

diazonium salts

nitro compounds

or

triazenes

Chart 5 
nitrosoacetanilides (4) were observed to adopt only conformer I. However, $2-\mathbf{4}$ may adopt conformer II or a similar form at the decomposition temperature, since these compounds decompose to generate a diazonium ion in carbon tetrachloride. ${ }^{9,10)}$

The rearrangement of this type in the (4-tolyl)nitrosourea (1b) competes with liberation of a nitrosyl radical as a source of the formation of the nitro compound (12), ${ }^{1)}$ as indicated in Chart 5. The 1-aryl-1-nitrosoureas readily form the NO radical in carbon tetrachloride at $33^{\circ} \mathrm{C},{ }^{1,10,11)}$ though the $\mathrm{N}$-NO bond cleavage of the aliphatic $N$-nitroso compounds proceeds by photolysis. ${ }^{12)}$ The generation of the NO radical is probably due to the contribution of conformer III, which has the partially conjugated system of $\mathrm{Ph} \ldots \mathrm{N} \ldots \mathrm{N} \ldots \mathrm{O}$, and the neighboring $\mathrm{CO}$ group, which accelerates the fission of the $\mathrm{N}-\mathrm{NO}$ bond owing to the electrostatic repulsion between the NO group and the $\mathrm{CO}$ group. This partial conjugated structure is supposed to be advantageous for moving one electron from the conjugated system of the aromatic ring to the NO group.

It is known that $N$-nitrosocarbazoles and $N$-nitrosodiphenylamines generate a nitrosyl radical under reflux in xylene or benzene, and give the corresponding nitro compounds. ${ }^{13)}$ These $N$-nitroso compounds also have a planar conformation with conjugation of the aromatic ring and the NO group. ${ }^{14)}$ If a conformation of this type is involved in the activation of $\mathrm{N}-\mathrm{NO}$ bond cleavage in nonpolar solvents, one may utilize this character to carry out nitrosation or nitration under mild conditions.

\section{Experimental}

${ }^{13} \mathrm{C}-\mathrm{NMR}$ spectra were measured with a JEOL FX-200 spectrometer with tetramethylsilane as an internal standard. The spectra were recorded under the following conditions; ${ }^{13} \mathrm{C}-\mathrm{NMR}$ at a frequency of $50.10 \mathrm{MHz}$ with a spectral width of $10000 \mathrm{~Hz}$; pulse width $4 \mu \mathrm{s}$; acquisition time $0.8192 \mathrm{~s}$; number of data points 16384 ; temperature of about $35^{\circ} \mathrm{C}$ for compounds $7-\mathbf{1 0}$ and $-40^{\circ} \mathrm{C}$ for compounds $1-6$. Chemical shifts are accurate to $\pm 0.05 \mathrm{ppm}$. The concentration used was $1.0-10 \times 10^{-5} \mathrm{~mol} / \mathrm{ml}$ of $\mathrm{CDCl}_{3}$ in each case.

Infrared (IR) spectra were taken with a JASCO A-102 spectrometer.

Materials - 1-Aryl-1-nitrosoureas $(\mathbf{1}, \mathbf{5}, \mathbf{6})$ were prepared by nitrosation of the corresponding ureas according to the method described in a previous paper. ${ }^{11}$

The ureas used as starting materials for nitrosation were as follows. 1-Phenyl-3,3-diethylurea: $\mathrm{mp} 89-90^{\circ} \mathrm{C}$. IR

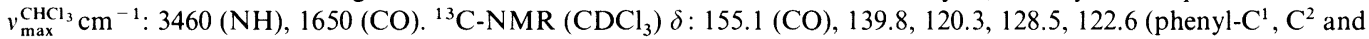

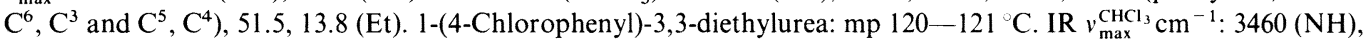
$1650(\mathrm{CO}) .{ }^{13} \mathrm{C}$-NMR $\left(\mathrm{CDCl}_{3}\right) \delta: 154.7(\mathrm{CO}), 138.3,121.5,128.5,127.6\left(\right.$ phenyl- $\mathrm{C}^{1}, \mathrm{C}^{2}$ and $\mathrm{C}^{6}, \mathrm{C}^{3}$ and $\left.\mathrm{C}^{5}, \mathrm{C}^{4}\right), 41.5$, 13.8 (Et). 1-Methyl-3,3-(pentamethylen)urea: mp 76-77 ${ }^{\circ} \mathrm{C}$. IR $v_{\max }^{\mathrm{CHCl}_{3}} \mathrm{~cm}^{-1}: 3475,3380^{\text {br }}$ (free and associated $\mathrm{NH}$ ), $1620(\mathrm{CO}) .{ }^{13} \mathrm{C}-\mathrm{NMR}\left(\mathrm{CDCl}_{3}\right) \delta: 158.9(\mathrm{CO}), 27.5\left(\mathrm{~N}\right.$-Me), 44.8, 25.7, 24.5 (piperidino- $\mathrm{C}^{1}$ and $\mathrm{C}^{5}, \mathrm{C}^{2}$ and $\left.\mathrm{C}^{4}, \mathrm{C}^{3}\right) .1$ Isopropyl-3,3-(pentamethylen)urea: $\mathrm{mp} 134-135^{\circ} \mathrm{C}$. IR $v_{\max }^{\mathrm{CHCl}_{3}} \mathrm{~cm}^{-1}: 3465,3400^{\mathrm{br}}$ (free and associated $\mathrm{NH}$ ), 1625 (CO). ${ }^{13} \mathrm{C}$-NMR $\left(\mathrm{CDCl}_{3}\right) \delta: 157.3(\mathrm{CO}), 42.4,23.3$ ( $N$-iso-Pr), 44.8, 25.7, 24.5 (piperidino- $\mathrm{C}^{1}$ and $\mathrm{C}^{5}, \mathrm{C}^{2}$ and $\mathrm{C}^{4}, \mathrm{C}^{3}$ ).

Nitrosoureas: 1-Phenyl-3,3-diethyl-1-nitrosourea (1c): Oil. IR $v_{\max }^{\mathrm{CHCl}_{3}} \mathrm{~cm}^{-1}: 1695$ (CO). Anal. Calcd for $\mathrm{C}_{11} \mathrm{H}_{15} \mathrm{~N}_{3} \mathrm{O}_{2}$ : C, 59.71; H, 6.83; N, 18.99. Found: C, 59.95; H, 6.92; N, 12.95. 1-(4-Chlorophenyl)-3,3-diethyl-1nitrosourea (1d): $\mathrm{mp} 45^{\circ} \mathrm{C}$ (dec.). IR $v_{\max }^{\mathrm{CHCl}_{3}} \mathrm{~cm}^{-1}: 1695$ (CO). Anal. Calcd for $\mathrm{C}_{11} \mathrm{H}_{14} \mathrm{ClN}_{3} \mathrm{O}_{2}: \mathrm{C}, 51.67 ; \mathrm{H}, 5.52 ; \mathrm{N}$, 16.43. Found: C, 52.19; H, 5.62; N, 16.81. 1-Methyl-3,3-(pentamethylen)-1-nitrosourea (5): $\mathrm{mp} 31^{\circ} \mathrm{C}(\mathrm{dec}$.) (hygroscopic). IR $v_{\max }^{\mathrm{CHCl}_{3}} \mathrm{~cm}^{-1}: 1680(\mathrm{CO})$. Anal. Calcd for $\mathrm{C}_{7} \mathrm{H}_{13} \mathrm{~N}_{3} \mathrm{O}_{2} \cdot 1 / 6 \mathrm{H}_{2} \mathrm{O}: \mathrm{C}, 48.26 ; \mathrm{H}, 7.72 ; \mathrm{N}, 24.12$. Found:

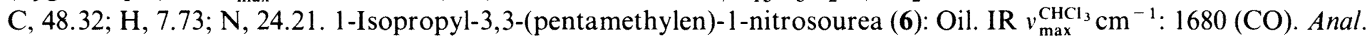
Calcd for $\mathrm{C}_{9} \mathrm{H}_{17} \mathrm{~N}_{3} \mathrm{O}_{2}: \mathrm{C}, 54.25 ; \mathrm{H}, 8.60 ; \mathrm{N}, 21.09$. Found: $\mathrm{C}, 53.98 ; \mathrm{H}, 8.64 ; \mathrm{N}, 20.89$. The analytical data for the disubstituted nitrosoureas $(\mathbf{2 b}, \mathbf{2 e}, \mathbf{3 a}-\mathbf{c})$ were reported in a separate paper. $\left.{ }^{10}\right)$

$\mathrm{N}$-Nitrosoacetanilides ${ }^{9,16)}$ and $\mathrm{N}$-nitrosoanilines ${ }^{2)}$ were prepared by the procedures cited. These compounds were chromatographed on silica gel with a mixture of $n$-hexane, ether and $\mathrm{CHCl}_{3}$. All of the purified nitroso compounds were yellow oils except for 9 b. $N$-tert-Butyl- $N$-nitroso-4-toluidine (9b): mp 53-54 C. Anal. Calcd for $\mathrm{C}_{11} \mathrm{H}_{16} \mathrm{~N}_{2} \mathrm{O}: \mathrm{C}$, 68.72; H, 8.39; N, 14.57. Found: C, 68.56; H, 8.49; N, 14.62 .

Decomposition of 1-Aryl-3,3-(pentamethylen)-1-nitrosoureas $\left(\mathbf{5 , 6 )}\right.$ in $\mathbf{C H C l}_{3}$-About $5.0 \times 10^{-5} \mathrm{~mol}$ of 1 isopropyl-3,3-(pentamethylen)-1-nitrosourea (6) in $1 \mathrm{ml}$ of $\mathrm{CHCl}_{3}$ was sealed in a $\mathrm{KBr}$ cell and the IR spectrum was taken at room temperature. The absorption intensity at $2320 \mathrm{~cm}^{-1}$ due to $\mathrm{CO}_{2}$ increased with the passage of time. ${ }^{1)} 1$ Methyl-3,3-(pentamethylen)-1-nitrosourea (5) remained intact during $10 \mathrm{~d}$ under the same conditions. 


\section{References and Notes}

1) S. Sueyoshi and M. Tanno, Chem. Pharm. Bull., 33, 488 (1984).

2) C. E. Looney, W. D. Phillips, and E. L. Reilly, J. Am. Chem. Soc., 79, 6136 (1957); G. J. Karabatsos and R. A. Taller, ibid., 86, 4373 (1964).

3) J. T. D'Agostino and H. H. Jaffe, J. Am. Chem. Soc., 92, 5160 (1970).

4) P. S. Pregosin and E. W. Randall, J. Chem. Soc., Chem. Commun., 1971, 399.

5) The location of alkyl groups of the disubstituted nitrosoureas is favorable in the $Z$ form with respect to the $C O$ group. Cf., J. K. Snyder and L. M. Stock, J. Org. Chem., 45, 886 (1980); C. N. R. Rao, K. G. Rao, A. Goel, and K. Balasubramanian, J. Chem. Soc. A, 1973, 3077.

6) In the case of conformer II, it may be energetically advantageous to locate the NO group between the two ethyl groups at the $\mathrm{N}^{3}$ position.

7) The proton at the $\mathrm{C}^{2}$ or $\mathrm{C}^{6}$ position in conformer III is located between the $\mathrm{X}$ group and the $\mathrm{CO}$ group.

8) R. Huisgen and L. Krause, Justus Liebigs Ann. Chem., 574, 157 (1951); M. Miyahara and S. Kamiya, Chem. Pharm. Bull., 30, 3466 (1982); S. S. Singer, J. Org. Chem., 47, 3839 (1982).

9) D. H. Hey, T. Stuart-Webb, and G. H. Williams, J. Chem. Soc., 1952, 4657; C. Rüchardt and C. C. Tan, Chem. Ber., 103, 1774 (1970).

10) M. Tanno and S. Sueyoshi, Chem. Pharm. Bull., 35, 1360 (1987).

11) The formation of the nitro compounds was depressed by a radical inhibitor. S. Sueyoshi and M. Tanno, Abstracts of Papers, 12th Symposium on Progress in Organic Reactions and Syntheses, November 1985, p. 111.

12) J. N. S. Tam, R. W. Yip, and Y. L. Chow, J. Am. Chem. Soc., 96, 4543 (1974).

13) P. Welzel, Chem. Ber., 104, 808 (1971).

14) L. Forlani, L. Lunazzi, D. Macciantelli, and B. Minguzzi, Tetrahedron Lett., 1079, 1451.

15) The isomer ratios could not be determined by integration of the ${ }^{1} \mathrm{H}-\mathrm{NMR}$ spectrum because of overlapping signals.

16) P. Miles and H. Suschitzky, Tetrahedron, 18, 1369 (1962). 